\title{
Postinterrupční syndrom
}

Karolina Diallo, Marie Lhotová

\section{Úvod}

Jednu z předních příček kontroverzních témat dlouhodobě zaujímá problematika interrupce, tedy umělého ukončení těhotenství. Jedná se o téma, které zaručuje živé debaty. Nicméně jakkoliv horlivé filosoficko-etické diskuze na toto téma jsou přebity intenzivní vnitřní bitvou, které čelí ženy konfrontovány s neplánovaným těhotenstvím a možností interrupce. Jde o konflikt hodnot, přesvědčení, touhy, nejistot i obav. Každý akademický argument pro, nebo proti interrupci byl zvážen tisíci žen zápasících se stejnými otázkami. Bezesporu existují ženy, pro které rozhodnutí o umělém ukončení těhotenství nepředstavuje žádnou psychickou zátěž. Jiné se pod tíhou okolností domnívají, že vlastně nemají na výběr, a činí rychlá a zdánlivě jednoznačná rozhodnutí. Avšak ta mohou mít vážné dopady na fyzický, emocionální, sociální i duchovní život ženy.

Můžeme se však setkat s názory, které se pohybují od škodlivosti diagnózy postinterrupčního syndromu, přes popírání jeho existence, až po názory poukazující na pozitivní vliv potratů na psychiku žen.

Proti vlastní diagnostice a empirickému zjišt'ování dalších symptomů stojí argumentace příznivců potratů, zastánců hnutí „pro-choice“ , kteří jej považují za manipulativní strategii, která má ženy odradit od svobodného rozhodování ohledně svého těhotenství. Dalším negativem diagnostikování postinterrupčního syndromu je dle nich skutečnost, že etiketa této diagnózy ženy viktimizuje negací jejich schopnosti činit vlastní rozhodnutí a nést jeho následky a vnucuje jim pozici závislých na druhých (nejčastěji partnerech či rodičích), kterými byly k potratu přinuceny. ${ }^{1}$ Podle organizace Parenthood Federation of America je popotratové trauma mýtem, nebot' údajně až 95 \% dotázaných žen potratu nelituje, a předkládá instrukce spíše medicínského rázu, jak o sebe po potratu pečovat. ${ }^{2}$ Členové této organizace zachází tak daleko, že vyzdvihují pozitivní př́inos zkušenosti s potratem. Potrat v sobě obsahuje rozhodování a úspěšné zvládnutí osobní krizové situace. ${ }^{3}$ Předkládají studie, které ukazují, že interrupce nezvyšuje riziko deprese, užívání drog nebo jakéhokoliv jiného psychického problému u ženy o nic více než nechtěné těhotenství a/nebo porod. Jako podporu tohoto postoje odkazuje na výsledky výzkumů speciálního panelu odborníků jmenovaného American Psychological Association (APA), které ovlivnily rozhodnutí APA vydat v roce 2005 oficiální prohlášení vyvracející spojitost mezi potraty a následným psychickým traumatem. ${ }^{4} \mathrm{Na}$ toto prohlášení zareagoval se svým výzkumným týmem psycholog David Fergusson. Během své longitudální studie sledoval ženy po dobu 25 let a zjistil, že u žen, které ukončily své těhotenství, se vyskytovalo sebevražedné chování, deprese, zneužívání návykových látek, úzkost a další psychické problémy, a to signifikantně. Problémy nebylo možné vysvětlit jiným faktorem. Tato studie je zajímavá i tím, že Fergusson se netají tím, že je stoupenec pro-choice a zarytý ateista, a nelze ho tedy

1 Srov. Radka JANEBOVÁ, Sociální problémy z aspektu gender, Hradec Králové: Gaudeamus, 2006, s. 57.

2 Srov. Nancy RUSSO - Amy DABUL, The Relationship of Abortion to Well-Being, Professional psychology: research and practice 1/1997,

s. 23-31, dostupné na: http:/ / plannedparenthood.org/Results_home.aspx?params=postabortion, citováno dne 20. 3. 2015.

3 Srov. Ezra MISHAN, O povaze milosrdenství. Jak argumentují zastánci „ženské volby“, Praha: Občanský institut, 1997 , s. 8.

4 Srov. APA Briefing Paper on the Impact of Abortion on Women (2005) citován podle David FERGUSSON - John HORWOOD - Elizabeth RIDDER, Abortion in young women and subsequent mental health, Journal of Child Psychology E Psychiatry 1/2006, s. 16-24. 
obviňovat z podjatosti pro zveřejnění výsledků, které nadto vyvrátily jeho výzkumné předpoklady o neexistenci postinterrupčního syndromu. Na podkladě svých výzkumů Fergusson kontaktoval APA, zpochybnil její vyjádření z r. 2005, že potrat nepředstavuje žádné riziko pro psychiku ženy, a APA své vyjádření odstranila s poznámkou, že je nutné provést další šetření. ${ }^{5}$

Dnes je postinterrupční syndrom považován za specifickou formu posttraumatické stresové poruchy. Zvažování možnosti interrupce až po přijetí konečného rozhodnutí je ve většině př́ípadů emocionálně velmi silným procesem doprovázeným pocitem bolesti, žalu, lítosti. Potrat je zásahem do tělesné i psychické integrity ženy a jako takový může být zkušeností traumatizující. Podobně jako u traumat z jiných př́čin se jedinci často snaží na prodělanou ",zkoušku“ zapomenout, odmítají nebo ignorují bolest, která může být jejím následkem. Mnohé z postižených žen na vědomé úrovni nespojují prožívané pocity emociálního dyskomfortu s potratem, potlačení však nemůže být považováno za efektivní způsob vyrovnání se s prožitou ztrátou.

\section{Rizikové faktory}

Vědci identifikovali velké množství statisticky významných faktorů určujících, které faktory mohou iniciovat rozvoj či agravovat průběh postinterrupčního syndromu. Přehled rizikových faktorů vztažených k osobě ženy a zohledňujících její osobní, sociální, lékařskou anamnézu předkládá APA ve své zprávě za rok $2008^{6}$ :

- ukončení těhotenství, které bylo chtěné nebo ženou považované za smysluplné

- $\quad$ pocit'ovaný tlak okolí ukončit těhotenství

- $\quad$ vnímaný nesouhlas partnera, rodiny a/nebo přátel s potratem

- nedostatek sociální podpory od ostatních

- osobnostní rysy, zejména nízké sebepojetí, pesimistické postoje, subjektivně vnímaná nízká kontrola nad vlastním životem

- psychické problémy v anamnéze před těhotenstvím

- pocity stigmatizace

- potřeba potrat před okolím utajit

- vystavení protipotratovým iniciativám

- absence či neschopnost využívat copingové strategie

- pocity závazku k těhotenství

- ambivalence týkající se rozhodnutí o potratu

- subjektivně snížená schopnost vyrovnat se s potratem

- dřívější potrat v anamnéze

- termín potratu v pozdější fázi těhotenství

- nízký věk (adolescence)

- nemožnost volby (vynucený potrat)

Zde je nutno připomenout, že rizikové faktory nejsou synonymem přičiny sine qua non, stejně tak jako př́itomnost jednoho či více rizikových faktorů z výše uvedeného výčtu nutně nepovede k rozvoji postinterrupčního syndromu. Stejně tak je třeba poznamenat, že př́iznaky postinterrupčního syndromu nemusí časově přímo navazovat na potrat, stejně jako se v konkrétním případě nemusí projevit každý z popsaných př́iznaků. Některé ze symptomů se mohou po 
potratu objevit okamžitě, jiné i po několika měsících a některé vůbec. Zda se u ženy rozvine postinterrupční syndrom, rozhoduje do velké míry její osobnost a okolnosti případu.

K diagnóze postinterrupčního syndromu postačí dva z níže uvedených symptomů7.

1) Vina. Vinu jedinec cítí, když poruší svůj vlastní morální kodex. Pro ženu, která si uvědomí - at' už před samotným potratem, nebo po něm -, že dala souhlas k zabití svého nenarozeného dítěte, je břemeno viny neúnosné. Je těžké poskytnout útěchu ženě, která potlačila jeden z nejsilnějších instinktů (tedy ten mateřský). Mnoho žen trpících postinterrupčním syndromem věří, že nepříjemné pocity, které proživají, jsou nevyhnutelné, jelikož jsou zaslouženým trestem za zradu vlastního morálního přesvědčení.

2) Úzkost. Úzkost je nepříjemný emocionální a fyzický stav, který se projevuje mimo jiné svalovým napětím, závratěmi, tachykardií, nauseou, bolestmi hlavy. Úzkost s sebou nese problémy s koncentrací, poruchy spánku, vtíravé myšlenky spojené se starostmi o budoucnost. Konflikt mezi morálními normami a rozhodnutím podstoupit potrat může být spouštěčem masivní úzkosti. Velmi často se stává, že projevy úzkosti žena nebude připisovat prodělanému potratu, a přesto se nevědomě začne vyhýbat všemu, co se týká dětí (a co tedy její úzkost živí). Úzkost může mít podobu napětí (neschopnost odpočívat, podrážděnost atd.) doprovázeného fyzickými projevy (závratě, bušení srdce, žaludeční nevolnost, bolesti hlavy atd.), starostmi o budoucnost, potížemi se soustředěním a poruchami spánku. Z hlediska psychologie je spouštěčem úzkosti konflikt, v tomto případě konflikt morálních, náboženských či sociálních norem, které žena interiorizovala a které odporují jejímu rozhodnutí podstoupit interrupci. Ačkoliv se úzkost v rámci postinterrupčního syndromu projevuje obecnými příznaky, velmi často je vysledovatelná (nevědomá) snaha ženy vyhnout se všemu, co se týká dětí.

3) Emoční utlumení. Mnoho žen si po potratu dává slib, že už nikdy nikomu nedovolí, aby je dostal do podobně zraňující pozice. Výsledkem je, že - často mimovědomě - začnou např. tvrdě pracovat, aby upozadily negativní emoce a vzpomínky na událost, což je jednak ochranou před psychickou bolestí, ale zároveň oslabením schopnosti vytvářet a udržovat blízké vztahy. Odříznutím se od vlastních emocí připíší nepř́ijemný zážitek jiné osobě, resp. pocit'ují, jako by nepatřil jim, čímž eliminují potratem zapřričiněnou inkongruenci.

4) Deprese a suicidální myšlenky. Těžká forma deprese se u žen, které zažily potrat, $\mathrm{v}$ anamnéze objevuje více než dvakrát častěji než u zbytku populace. ${ }^{8}$ Lze u nich pozorovat pokles nálady od pocitů melancholie až k celkové beznaději, náhlé nekontrolovatelné epizody pláče ze zdánlivě neznámých (či nepochopitelných) přičin, zhoršené sebepojetí, nespavost, pokles chuti k jídlu a/nebo snížená chut' na sex, snížená motivace k vykonávání každodenních činností, ztráta zájmu o dříve oblíbené aktivity, narušení mezilidských vztahů (zejména $\mathrm{k}$ těm, kteří se podíleli na rozhodnutí o potratu). Sebevražedné myšlenky se objevují přibližně u 60 \% žen s postinterrupčním syndromem, 28 \% se o sebevraždu pokusilo, z nichž polovina opakovaně. ${ }^{9}$

\footnotetext{
7 Srov. Paul REISSER - Teri REISSER, A Solitary sorrow, Colorado Springs: WaterBrook Press, 2000, s. 53.

8 Srov. Jesse COUGLE - Danielle REARDON - Priscilla COLEMAN, Depression associated with abortion and childbirth: a long-term analysis of the NLSY kohort, Med Sci Montoring 4/2003, s. 105-112.

9 Srov. Mika GISSLER - Cynthia BERG - Marie-Helene BOUVIER-COLLE - Pierre BUEKENS, Injury deaths, suicides and homicides associated with pregnancy, European Journal of Public Health 5/2005, s. 459-463.
} 
5) Výročí. 54\% postižených žen hlásí zhoršení příznaků v období kolem výročí potratu a/nebo termínu porodu dítěte. ${ }^{10}$

6) Znovuprožívání interrupce. Velmi častým zážitkem popisovaným ženami s postinterrupčním syndromem jsou náhlé, zúzkostňující, opakující se flashbacky (zábleskové vzpomínky) související s potratem, zejména v situacích, které některými svými charakteristikami interrupci připomínají, jako např. běžné gynekologické vyšetření nebo i zvuk vysavače. Flashbacky se také objevují v podobě opakujících se nočních můr $\mathrm{o}$ dětech obecně nebo o vlastním ztraceném dítěti. $\mathrm{V}$ těchto snech se objevují témata ztracených, roztrhaných nebo plačících dětí.

7) Touha znovu otěhotnět. Významné procento žen dobrovolně otěhotní po umělém ukončení těhotenství v časovém horizontu jednoho roku a mnoho z nich přiznává přání otěhotnět tak rychle, jak je to možné. Nově počaté dítě má bud' odčinit vinu, nebo může představovat nevědomou touhu nahradit dítě, jehož život byl interrupcí ukončen. ${ }^{11}$

8) Obavy týkající se plodnosti a bezproblémového těhotenství. Společné ženám trpícím postinterrupčním syndromem jsou obavy, že se jim již nepodaří otěhotnět nebo že dítě nedonosí. Některé očekávají narození postiženého dítěte, jelikož dřivějším potratem se "diskvalifikovaly z role dobré matky“, mnohé se odkazují na Boží trest.

9) Ukončení tvorby emoční vazby se současným potomkem (je-li v rodině) a/nebo narušení vytváření této vazby s dítětem budoucím. Strach z další zničující ztráty může ženě po potratu ztížit, resp. znemožnit vytvořit skutečné emocionální pouto s ostatními dětmi. Další obvyklou reakcí na potrat je odčinění své viny snahou být současným nebo budoucím dětem dokonalou matkou. Žena, která v době potratu již matkou je, může zjistit, že po potratu své děti vidí v jiném světle: na jedné straně je mưže nevědomě trestat za to, že jim bylo dovoleno žít, nebo naopak je začne př́liš ochraňovat. Potrat je vedle snížení emocionálního pouta s dítětem spojen se zvýšenou depresivitou, násilným chováním, zneužíváním alkoholu a drog - kombinace těchto faktorů může vyústit ve zneužívání dětí. Klinické studie potvrzují korelaci postinterrupčního traumatu a následného syndromu CAN. ${ }^{12}$

10) Vina přeživšího. Většina žen se nerozhodne $\mathrm{k}$ interrupci na základě triviálních důvodů. Většinou si svou situaci interpretují jako velmi tíživou s tím, že pokud se rozhodnou dítě donosit, musí mnoho obětovat. Tímto prizmatem se jejich rozhodnutí ve finále scvrkává na smutnou volbu mezi sebou nebo dítětem, ve které vybírají sebe. Zatímco potrat ženu osvobodí od aktuálního traumatu, často $\mathrm{v}$ ní zanechá nepolevující pocit viny za preferování vlastního pohodlí za cenu života dítěte.

11) Sexuální dysfunkce. 30-50 \% žen, které mají obtíže vyrovnat se s potratem, trpí některou z forem sexuální dysfunkce, a to jak krátkodobě, tak i po dlouhou dobu, která začíná ihned po provedení potratu. Tyto problémy mohou zahrnovat jeden nebo více z následujících příznaků: ztráta potěšení z pohlavního styku, bolestivost koitu, odpor k sexu a/nebo mužům obecně, rozvoj promiskuitního životního stylu. ${ }^{13}$

\footnotetext{
10 Srov. tamtéž, s. 462.

11 Srov. tamtéž.

12 Srov. Philip NEY, Relationship between Abortion and Child Abuse, Canadian Journal of Psychiatry 24/1979, s. 610-620.

13 Srov. Anne SPECKHARD, Psycho-social Stress Following Abortion, Kansas City: Sheed \& Ward, 1987, s. 26
} 
12) Rozvoj poruch přijmu potravy. U některých žen se po interrupci rozvinula mentální anorexie nebo mentální bulimie. I když je tento fenomén v současné době stále $\mathrm{z}$ velké části neprozkoumaný, pro rozvoj poruch př́ijmu potravy hovoří hned několik psychologicky vysvětlitelných faktorů. Jednak výrazné zvýšení nebo snížení tělesné hmotnosti fyziologicky snižuje pravděpodobnost otěhotnění, které u některých žen postižených postinterrupčním syndromem nemusí být žádané. Nadto jsou obezita či extrémní vyhublost $\mathrm{v}$ dnešní společnosti považovány za neatraktivní a jako takové se stávají větší či menší překážkou k nalezení vhodného partnera, s kterým by žena otěhotnět mohla. Neatraktivita může být i formou sebetrestání a pomáhá ženě udržovat přesvědčení, že není hodna něčí pozornosti. Dále přísná kontrola stravovacích návyků představuje oblast útěchy ženám, které mají pocit, že svůj život nemůžou jinak ovládat.

13) Abúsus alkoholu a drog. Alkohol či drogy často slouží postiženým ženám jako způsob samoléčby, patologická strategie, jak se vypořádat s bolestí a vzpomínkami na potrat. Smutné je, že žena, která se uchýlí k alkoholu a/nebo drogám, se nakonec ocitne s více (a závažnějšími) problémy, ale zároveň s méně prostředky k jejich řešení. Nadužívání alkoholu či drog totiž negativní symptomy, které žena v akutní fázi postinterrupčního syndromu má, zesílí.

14) Další autopunitivní a sebedestruktivní jednání. Kromě poruch příjmu potravy a zneužívání návykových látek se žena s postinterrupčním syndromem může vrhat do neperspektivních a komplikovaných vztahů, může se stát promiskuitní, na vědomé i nevědomé rovině se může zraňovat fyzicky i emocionálně.

15) Akutní přechodné psychotické symptomy. Zřridka může žena po interrupci zažít psychotickou epizodu trvající maximálně dva týdny. Proces ataky a následné remise je velmi rychlý a ve většině případů dojde $\mathrm{k}$ úplné integraci ženiny osobnosti bez reziduí. I když se psychotická symptomatika jako reakce na prodělaný potrat objevuje vzácně, stojí za zmínku, jelikož osoba, u které se krátkodobě objeví psychotické reakce na stresovou událost, nemusí být nutně označena za psychotika. Během této epizody dochází k poruchám vnímaní i myšlení, proto by těmto jedincům měla být poskytnuta profesionální péče psychiatrická i psychologická.

Následující kazuistiky popisují psychické obtíže dvou žen, které prodělaly umělé ukončení těhotenství. Podoba jejich následných obtíží je dána osobnostními rysy, ranými zážitky, kontexty jejich života, ale nese řadu symptomů společných stavům po interrupci popisovaným $\mathrm{v}$ literatuře a z kontextu je zřejmé, že se k ukončení těhotenství vztahují.

\section{Kazuistika I}

Žena byla třikrát vdaná, ale ani s jedním manželem nemohla otěhotnět. Otěhotněla nečekaně s bývalým spolužákem. Navzdory tomu, že si dítě dříve velmi přála, rozhodla se toto těhotenství ukončit. Rozhodnutí popisuje $z$ hlediska času jako překotné, ale neprožívala žádné intenzivní emoce ani předtím, ani při odchodu z nemocnice. Cítila se, jako by nechala utratit psa, a truchlení nepřikládala žádný význam, takže mu nenechala prostor. V oblasti sexu neměla následně žádné problémy. Psychické problémy se vynořily po několika měsících. Ztrácela chut' do života, přestala ji bavit práce. I po změně zaměstnání zůstávala situace stejná. Začala o sebe úzkostně pečovat, předmětem zájmu se stal vnější vzhled, oblékání, kosmetika, masáže, zdravá výživa. Ošetřování 
a péče o tělo ale nepomohly, $v$ té době se začaly objevovat poruchy spánku, úzkosti v uzavřeném prostoru a symptomy mentální anorexie. Klientka opustila práci, nechala se zaregistrovat na úřadu práce a uzavřela se do sebe natolik, že prakticky přestala vycházet $z$ domu. Dostala od obvodního lékaře psychofarmaka, ale psychiatrem nabízenou hospitalizaci odmítla. Dvakrát týdně docházela na psychoterapii, ve zbývajícím čase doma ležela abulická, neschopná něco dělat. Několikrát plánovala sebevraždu. $\mathrm{V}$ průběhu psychoterapie se při rekapitulaci života vynořily události z dětství, a to z období, ve kterém její teta, sestra matky, zemřela při porodu dítěte a oba její rodiče (prarodiče klientky) si v návalu následného žalu sáhli na život a zemřeli strangulací. Její matka od smrti své sestry nebyla schopna snést, kdykoliv se začalo mluvit o porodech. $\mathrm{V}$ takové situaci s pláčem utíkala z místnosti. Když se v průběhu terapie klientky objevilo téma jejího potratu, mluvila o něm jako o "tom“ („když se stalo tamto“) a držela se za podbřišek, jako když cítí bolest. Bolest však popírala, ale mluvila o prázdné černé díře v sobě, kterou přirovnávala k obrázku s vystřiženým středem. Poslední část několikaměsíční psychoterapie se věnovala bilancování a úvahám o tom, co v životě si zaslouží a co nikoliv. Ještě občas stávala u výloh s dětským oblečením, kočárky s dětmi tlačené maminkami nesnášela a nejdéle u ní přetrvávala averze $k$ těhotným ženám. Její psychický stav se však upravil natolik, že začala podnikat, o svých klientkách hovořila láskyplně v tom smyslu, že o ně pečuje jako o miminka. Otázku, zda si je jistá, že jim to je př́ijemné, ponechala bez komentáře.

\section{Kazuistika II}

Mladá žena žijící v dlouhodobém vztahu s partnerem neplánovaně otěhotněla. Ani jeden z nich se necítil připraven převzít roli rodičů. Partner ponechal prostor k rozhodnutí o dalším osudu ženě. Žena se cítila slabá bez podpory partnera a rozhodla se své těhotenství ukončit. Bylo to $\mathrm{v}$ době, kdy už měla ve skříni pro své dítě připravené malinké oblečení. Dítě se nenarodilo, už nikdy potom o něm s partnerem nemluvili a jejich vztah se rozpadl. Ještě dvakrát se jej pokoušeli obnovit, ale nikdy se to nepodařilo. Žena odjela na určitou dobu pracovat do ciziny. Osm let po potratu, už zpátky doma, se objevily stavy úzkostné deprese. Při terapii se vynořilo téma potratu. Za nejtěžší považovala to, že její bývalý partner už žil s jinou ženou, se kterou má dítě. Depresivní stavy se postupně v průběhu času podařilo zredukovat, ale přetrvávala anhedonie. Klientka žila ve smutku, chyběla spontánnost a uvolněnost, i když začala nový vztah a výbavičku schovanou 8 let ve skříni někomu věnovala.

\section{Závěr}

Otázka, zda a do jaké míry souvisí interrupce s duševním zdravím, byla položena mnohokrát několika různými způsoby. S ohledem i na legální aspekty problému nejčastěji padá dotaz, zda má interrupce negativní dopad na duševní zdraví ženy. Nejen vědecké, ale i etické aspekty snižují naši schopnost podat jednoznačnou odpověd' na tuto otázku. Stručně řečeno, psychická reakce na prodělanou interrupci není a ze své podstaty ani nemůže být uniformní. Mění se v závislosti na osobnostních rysech, na událostech, které předcházely či vedly k těhotenství, reflektuje okolnosti ženina života a vztahů v době, kdy se o ukončení těhotenství rozhodovala. Tyto a mnoho dalších proměnných je třeba vzít v úvahu při zkoumání tohoto jevu. Existenci postinterrupčního syndromu u žen, které podstoupily umělé ukončení těhotenství, klinický výzkum prokázal a poukázal na to, že jeho rozvoj závisí na vícero faktorech. Jsou to podmínky 
(osobní, sociokulturní aj.) v životě ženy, které mohou být klíčové pro duševní zdraví obecně, bez ohledu na příp. nechtěné těhotenství a způsob jeho řešení, ale taktéž přehodnocení postoje k těhotenství, k potratu či schopnost ženy zvolit a akceptovat jednu možnost. Odráží také disponibilitu a aplikaci vhodných copingových strategií, práci s vlastními emocemi.

\section{Postinterrupční syndrom}

Abstrakł Článek svým zaměřením rozvijí kontroverzní téma umělého ukončení těhotenství v souvislosti s jeho možnými dopady na psychické zdraví ženy v podobě nezrídka se objevujícího postinterrupčního syndromu. Postinterrupční syndrom je souborem symptomů, které se u některých žen dostavuji po uměle vyvolaném potratu. Nemá vlastní diagnostickou kategorii, je považován za specifickou formu posttraumatické stresové poruchy. Projevuje se obecnými symptomy, které můžeme nalézł u posttraumatické stresové poruchy, ale taktéž symptomy specifickými, na které se text článku zaměřuje a které analyzuje s odkazem na odbornou literaturu. Dále článek upozorňuje na rizikové faktory, které byly stanoveny Americkou psychologickou asociací jako ty, které iniciuji či ztěžují průběh postinterrupčního syndromu. Teoretický text je zakončen dvěma kazuistikami žen, kterým byl diagnostikován postinterrupční syndrom, resp. forma posttraumatické stresové poruchy $\vee$ prímé souvislosti s podstoupeným umělým ukončením těhotenství.

Klíčová slova potrat, psychická reakce na interrupci, postinterrupční syndrom, rizikové faktory postinterrupčního syndromu

\section{Post-Abortion Syndrome}

Abstract The paper develops the controversial topic of artificial termination of pregnancy in connection with its possible impact on the woman's mental health in the form of the not infrequently appearing post-abortion syndrome. Post-abortion syndrome is a set of symptoms which in some women appear after an artificially induced abortion. It does not have its own diagnostic category and is considered to be a specific form of post-traumatic stress disorder. It manifests itself by general symptoms, which we can find in a post-traumatic stress disorder, but also by specific symptoms, on which the text of the paper focuses and which it analyses with reference to the literature. The paper further points out the risk factors identified by the American Psychological Association as those initiating or aggravating the course of post-abortion syndrome. The theoretical text is concluded by two case studies of women in whom post-abortion syndrome, or a form of post-traumatic stress disorder in direct connection with undergone artificial termination of pregnancy, was diagnosed.

Keywords abortion, psychological responses to abortion, post-abortion syndrome, risk factors for PAS 